\title{
A Primeira Lei das Sociedades Anônimas no Brasil* Lei no 1.083 - 22 de Agosto de 1860
}

\author{
The First Company Law in Brazil \\ Act $n^{\underline{0}} 1.083$ - August 221860
}

\section{Sérgio de ludícibus}

Professor Aposentado da FEA-USP, da qual foi Diretor, e Professor do Curso de Pós-Graduação em

Ciências Contábeis e Financeira da PUC-SP

\section{Álvaro Augusto Ricardino Filho}

Doutorando em Controladoria e Contabilidade pela FEA-USP

RESUMO

Este artigo procura demonstrar que uma lei pouco conhecida do meio contábil, a Lei № 1.083 de 22 de Agosto de 1860, em que pesem as limitações sócio-econômicas da época, é de fato a primeira Lei das Sociedades Anônimas no Brasil, diferentemente do conceito vigente que adota a Lei 2.627, de 1940, como tal. Adicionalmente, apresenta os modelos de publicação de balanços contidos no texto da lei e alguns exemplos de balanços publicados naquela época (inéditos) que mostram que o padrão criado era efetivamente seguido e servia de orientação às publicações ocorridas até por volta de 1940.

Por último destaca-se que as circunstâncias que cercaram a elaboração da referida lei transformaram a contabilidade em um instrumento de repressão e vigilância das atividades privadas, uso pouco convencional e nada similar ao que dela se espera nos dias de hoje.

Palavras-chave: História da Contabilidade e Lei das S.As.
ABSTRACT

This article seeks to demonstrate that a little known law in the accounting area, that is, Act $N^{\circ}$ 1.083, from August 22 1860, is actually the first Law on Company Law in Brazil. This is different from the concept in vigour, which adopts Act $N$ o 2.627, from 1940, as such. In addition, the publication models for balance sheets contained in the law text are presented, which show that the standard created was really followed and served as an orientation for the publications realised until about 1940.

Finally, it is highlighted that the circumstances surrounding the elaboration of the law referred to transformed accounting into an instrument for repressing and guarding private activities, a hardly conventional use which is not at all similar to what is expected from it nowadays.

Key words: History of Accounting, company Law in Brazil.

\footnotetext{
* Artigo originalmente apresentado no II Accounting History International Conference, Osaka - Japan - Agosto/2001 
INTRODUÇÃO

Há um consenso, quase que generalizado entre os profissionais e estudiosos da contabilidade, segundo o qual a primeira Lei das Sociedades Anônimas $^{1}$, no Brasil, foi promulgada pelo Decreto Lei $n^{\circ}$ 2.627 , de 1940. Na ocasião, esse diploma legal estabeleceu procedimentos para a contabilidade nacional, tais como regras para avaliação de ativos e para a apuração e distribuição de lucros. Determinou, ainda, a criação de reservas e os padrões para a publicação do balanço e da demonstração de lucros e perdas.

Os autores que defendem o pioneirismo da lei estão absolutamente corretos no que diz respeito a avaliação dos ativos e as regras para apuração e distribuição de lucros, porém, o mesmo não se dá com os padrões para a publicação dos balanços.

Uma antiga lei, de número 1.083, datada de 22 de Agosto de 1860, dez anos após a publicação do Código Comercial Brasileiro, e de certa forma editada para corrigi-lo em alguns aspectos, determinava a obrigatoriedade de publicar e remeter ao Governo, nos prazos e pelo modo estabelecido nos seus Regulamentos, os balanços, demonstrações e documentos que por estes forem determinados...

Essa lei, que viria a ser regulamentada pelo Decreto № 2.679, orientou, ao longo dos oitenta anos seguintes, as publicações ocorridas em todo território nacional.

Adicionalmente, o trabalho apresenta, a título comparativo com os modelos legais, alguns balanços publicados na época, até hoje pouco conhecidos dos profissionais da área contábil e do público em geral.

O objetivo deste trabalho é resgatar, não apenas o texto da lei e seus anexos, mas, fundamentalmente, recuperar, ainda que de forma bastante resumida, as circunstâncias sócio-econômicas e culturais que determinaram a redação e edição dessa lei, recurso pouco comum nos escassos artigos que dissertam sobre a história da contabilidade em nosso país. Tal recurso faz com que, por

${ }^{1}$ A esse respeito vide, entre outros, SILVA (1980, p. 18), FRANCO (1988, p. 55), SCHMIDT (2000, p. 207).

\section{INTRODUCTION}

There exists an almost generalised consensus between accounting professionals and scholars, in accordance to which the first Company Law ${ }^{1}$, in Brazil, was issued by Decree Act № 2.627, from 1940. On that occasion, this legal certificate established procedures for national accounting, such as rules for valuating assets and for verifying and distributing profits. It also determined the creation of reserves and standards for publishing the balance sheet and the profit and loss statement.

The authors defending the pioneering character of this law are absolutely correct in relation to the valuation of assets and the rules for verifying and distributing profits, even though the same is not true of the publication of standards for balance sheets.

An ancient act, numbered 1.083, dated August 22 1860, ten years after the publication of the Brazilian Commercial Code, and to a certain extent edited in order to correct it in some aspects, determined the obligation to publish and forward to the Government, in accordance with the terms and ways established in its Regulations, the balance sheets, statements and documents that were determined by them...

During the following eighty years, this law, which would be regulated by Decree No 2.679, guided the publications that occurred in the entire national territory.

In addition, under the pretext of comparing them with the legal models, this work presents some balance sheets published in that age, which are until now little known to the accounting professionals and to the public in general.

The aim of this work is to rescue not only the law text and its annexes, but, basically, to recover, although in a rather summarily way, the socio-economic and cultural circumstances that determined the composition and edition of this law, a resource which is not very common to the rare articles that dealt with the history of accounting in Brazil. Due to such a

\footnotetext{
${ }^{1}$ With respect to this subject, vide, among others, SILVA (1980, p. 18), FRANCO (1988, p. 55), SCHMIDT (2000, p. 207)
} 
vezes, a temática contábil seja colocada em segundo plano, substituída pela narrativa histórica, não obstante se retorne à primeira assim que os acontecimentos se fecham em torno do aspecto contábil pesquisado.

Para que o propósito deste trabalho seja alcançado é necessário retroceder um pouco além daquela época.

\section{O PANORAMA SOCIAL BRASILEIRO AO FINAL DO SÉCULO XVIII.}

Até o final do século XVIII, o Brasil sofria as restrições inerentes à sua condição de colônia portuguesa e era alvo de toda sorte de proibições que tinham por objetivo sufocar quaisquer pensamentos separatistas. O comércio era prerrogativa exclusiva dos cidadãos de origem portuguesa e qualquer tipo de manufatura era terminantemente proibida pela Carta Régia de 1785, exceção feita às "fazendas grossas de algodão que serviam para uso e vestuário dos negros e para enfardar ou empacotar fazendas ou para outros ministérios semelhantes". ${ }^{2}$ Até mesmo os bordados manuais eram vetados.

O temor pela liberdade era tal que algumas das proibições beiravam o ridículo, como a que em 1795 solicitava a extinção da cadeira de filosofia nos conventos, posto que não convinha "abusar dos estudos superiores que só servem para nutrir o orgulho próprio aos habitantes ${ }^{3}$....".

Diante desse quadro, torna-se absolutamente compreensível que D. João VI, ao aportar no Rio de Janeiro em 1808, tenha determinado uma série de medidas que, em caráter emergencial, tentavam estabelecer um mínimo de governabilidade ao país no qual se refugiava das tropas napoleônicas. Não o fez pelo Brasil, mas por si próprio e pelo bem estar da corte que encabeçava. Vale destacar que, em 1808, o Rio de Janeiro contava com cerca de trinta mil habitantes e que, em menos de um ano, cerca

\footnotetext{
${ }^{2}$ Sobre o assunto vide SIMONSEN (1939, p. 21)

${ }^{3}$ Fialho $(1938$, p.331)
}

resource, the accounting theme is sometimes moved to the background and substituted for by the historical narrative, although the former is returned to as soon as the events close in on the accounting aspect researched.

In order to reach the objective of this work, it is necessary to go back a bit beyond that time.

\section{THE BRAZILIAN SOCIAL PANORAMA} AT THE END OF THE XVIIITH CENTURY

Until the end of the XVIIIth century, Brazil suffered the restrictions that were inherent to its state of Portuguese colony and was the target of all sorts of prohibitions aimed at suffocating any separatist ideas. Commerce was the exclusive prerogative of citizens of Portuguese origin, and any kind of manufacturing was categorically forbidden by the Carta Régia from 1785 , the only exception being made for the "fazendas grossas de algodão que serviam para uso e vestuário dos negros e para enfardar ou empacotar fazendas ou para outros ministérios semelhantes". ${ }^{2}$ Even manual embroidery was vetoed.

The fear of liberty was such that some of the prohibitions bordered ridicule, like the one that, in 1795, sought the extinction of the philosophy chair in the convents, since it was not suitable that this position would "abusar dos estudos superiores que só servem para nutrir o orgulho próprio aos habitantes ${ }^{3}$...".

In view of this picture, it becomes absolutely comprehensible that $D$. João VI, King of Portugal, when he arrived in Rio de Janeiro in 1808, determined a series of measures that, as emergency laws, tried to establish a minimum of governableness in the country to which he flew from the Napoleonic armies. He did not do this for Brazil, but for himself and for the wellbeing of the court which he headed. It should be highlighted that, in 1808, there were about thirty thousand inhabitants in Rio de Janeiro and that, in

\footnotetext{
2 (trans.) "thick cotton cloth that served for the use and clothing of negroes and for packing cloth or for other similar purposes." On this issue, vide SIMONSEN (1939, p. 21)

3 (trans.) "abuse the higher studies that only serve to feed the pride characteristic of the inhabitants..."

Fialho (1938, p.331)
} 
de quinze mil portugueses desembarcaram na cidade acompanhando a real família. A cidade se encontrava completamente despreparada para receber tal contingente.

O panorama sócio econômico no Rio de Janeiro no início do século XIX.

Nas décadas seguintes, o Brasil, mais particularmente o Rio de Janeiro, viria a conhecer um irreversível, porém moroso processo de transformação econômica. Para que se tenha idéia da lentidão desse processo, basta registrar o minimalismo das iniciativas industriais ocorridas nos anos subseqüentes ${ }^{4}$ :

- 1812 - Fábrica de Ferro da Villa de Sorocaba.

- 1812 - Fábrica de Pólvora na lagoa Rodrigo de Freitas.

- 1813 - Fábrica de cartas de baralho no R.J.

- 1816 - Imprensa Real e o jornal periódico Gazeta do Rio de Janeiro.

- 1817 - Exploração de salinas no Rio de Janeiro.

- 1819 - Fábrica de tecidos na lagoa Rodrigo de Freitas.

- 1822 - Curtume em São Cristóvão.

- 1823 - Fundiçãoparasinos.

- 1823 - Fábrica de armas, com 200 operários.

- 1823 - Fábrica de fiação e tecidos em S. Paulo.

- 1823 - Engenhos de cana e moinhos a vapor.

- 1831 - Fundação da Sociedade de Incentivo à Indústria.

- 1831 - diversas tipografias e 15 jornais.

Um interessante testemunho dessa "capacidade" industrial do país foi prestado por um conde francês de nome Suzanet que, em visita ao Rio de Janeiro, em 1845, assim se expressou sobre o assunto: "A indústria manufatureira faz, no dizer dos brasileiros, grandes progressos. Já se fabrica sabão, papel e selaria comum. Foi fundada uma fábrica de cristais no Rio de Janeiro. (...) não há nenhuma fábrica importante no Brasil ${ }^{5}$..."

As razões de tal estagnação estavam relacionadas com a incapacidade das exportações gerarem divisas suficientes para financiar a aquisição dos ati- less than one year, about fifteen thousand Portuguese disembarked in the city, accompanying the royal family. The city was completely unprepared for receiving such a contingent.

The socio-economic panorama in Rio de Janeiro at the beginning of the XIXth century

In the following decades, Brazil, and more particularly Rio de Janeiro, got to know an irreversible, but nevertheless slow process of economic transformation. In order to imagine the slowness of this process, it is sufficient to register the minimalism of the industrial initiatives that occurred in the following years ${ }^{4}$ :

- 1812 - Iron factory in Sorocaba Village.

- 1812 - Gunpowder factory at the Rodrigo de Freitas lagoon.

- 1813 - Playing-cards factory in Rio de Janeiro.

- 1816 - Royal Press and the newspaper Gazeta of Rio de Janeiro.

- 1817 - Exploration of salt-works in Rio de Janeiro.

- 1819 - Cloth factory at the Rodrigo de Freitas lagoon.

- 1822 - Tanneryin São Cristóvão.

- 1823 - Foundry forbells.

- 1823 - Arms factory, with 200 workers.

- 1823 - Line and cloth factory in S. Paulo.

- 1823 - Sugar cane mills and steam mills.

- 1831 - Foundation of the Industrial Incentive Society.

- 1831 - Variousprintingofficesand15newspapers.

An interesting testimony of the country's industrial "capacity" was given by a French count called Suzanet who, when he visited Rio de Janeiro in 1845, expressed himself on the issue in the following way: "In accordance with the Brazilians, the manufacturing industry is making great progress. Soap, paper and common saddlery are already being fabricated. A factory of cristal was founded in Rio de Janeiro. (...) there is not any important factory in Brazil, ${ }^{5}$..."

The reasons for such stagnation were related to the incapacity of the exports to create sufficient financial resources for financing the acquisition of

\footnotetext{
${ }^{4}$ Source: Collection laws of Brazil.

${ }^{5}$ Our italics.
} 
vos necessários à industrialização do país. Nos dizeres do Prof. Celso Furtado, a causa principal do grande atraso relativo à economia brasileira na primeira metade do século XIX foi o estancamento de suas exportações. "Fomentar a industrialização nessa época, sem o apoio de uma capacidade para exportar em expansão, seria tentar o impossível num país totalmente carente de base técnica".

Foi somente em 1846 que o Brasil entrou de fato na era industrial. Naquele ano, Irineu Evangelista de Souza, futuro Barão de Mauá, adquiriu a Fundição e Estaleiro Ponta de Areia, em Niterói. Para Caldeira, "a primeira indústria digna desse nome instalada no Brasil. Trocar o comércio pela indústria, no Brasil, era quase uma loucura naquela época".

A "quase loucura" a qual o autor se refere merece algumas explicações.

As atividades econômicas naquela época limitavam-se ao comércio e à agricultura, tocada por trabaIho escravo, onde o papel dos donos do capital era ordenar a derrubada do mato, comprar escravos, construir sedes de fazenda, preparar o solo e a semeadura, orientar a colheita e comercializá-la. Nas atividades comerciais, os mais bem sucedidos viviam das importações e exportações e, principalmente, do lucrativo tráfico de escravos.

Nessa sociedade não havia indústrias, até porque as atividades exercidas dentro dela necessitavam de trabalho manual e, conforme ensina Caldeira, qualquer atividade dessa espécie, por mais remunerada que fosse, era considerado degradante para os cidadãos livres. $O$ trabalho era uma atividade para escravos e provocava arrepios em pessoas que se consideravam bem-nascidas. "Esse desprezo ao trabalho era fundamental para marcar uma diferença social básica nas sociedades escravistas, nas quais distinção se confundia com não se sujeitar a tarefas consideradas humilhantes".

Por tais comportamentos, não é de se estranhar que Mauá fosse incompreendido pela sociedade local quando resolveu comprar a Fundição e Estaleiro da Ponta de Areia. A partir dessa aquisição a figura de Mauá estaria para sempre marcada na história do país e nos desdobramentos legais utilizados como meio de cercear suas atividades. No bojo das leis the assets necessary for the industrialisation of the country. In accordance with Prof. Celso Furtado, the main cause for the great delay related to the Brazilian economy in the first half of the XIXth century was the blockage of its exports". "To feed the industrialisation in that age, without the support of an export capacity in expansion, would be trying the impossible in a country with a complete lack of technical basis".

It was only in 1846 that Brazil actually entered the industrial age. In that year, Irineu Evangelista de Souza, the future Baron of Mauá, acquired the Foundry and Shipyard Ponta de Areia, in Niterói. For Caldeira, "the first industry worth this name installed in Brazil. In that age, to exchange commerce for industry in Brazil was almost madness".

The "almost madness" referred to by the author deserves some explanation.

In that age, the economic activity was limited to commerce and agriculture, realised by slave labour, in which the role of the capital owners was to command the destruction of the bushes, to buy slaves, to construct the headquarters of the farm and to wait for the crop. In the commercial activities, the most successful ones lived from imports and exports and, mainly, from the profitable traffic of slaves.

In this society, there were no industries, even because the activities exercised within it needed manual work and, in accordance with Caldeira, whichever activity of this kind, even if it were wellpaid, was considered degrading for free citizens. The work was an activity for slaves and sent shivers to people that considered themselves well-born. "This contempt of work was fundamental for marking a basic social difference in the slave societies, in which distinction was confounded with not subjecting itself to tasks that were considered humiliating".

As a result of such behaviour, it cannot be found strange that Mauá was not understood by the local society when he decided to buy the Foundry and Shipyard Ponta de Areia. From this acquisition onwards, the figure of Mauá would remain marked in the history of the country and in the legal deployments used as a means of cutting back his activities. In the 
apareciam nossos primeiros padrões e orientações contábeis.

\section{O CÓDIGO COMERCIAL BRASILEIRO}

As leis não surgem por acaso e nem da noite para o dia. A evolução sócio-econômica do país, ainda que bastante modesta àquela altura ${ }^{6}$, principiava a exigir regras mais claras para seu exercício. Para tanto, foi constituída uma comissão formada especificamente para esse fim e com relevante participação do já citado Barão de Mauá, como pode ser depreendido do texto a seguir:

"Em 1851 seria criado o Banco do Commercio e da Industria do Brasil. [...] Uma empresa como aquela não poderia ser fundada sem o novo Código Comercial, que entre outras coisas previa a formação de sociedades anônimas. No momento em que a lei foi escrita [1850] não havia o menor indício de gente disposta a fundar uma delas - mas o industrial travestido de redator de leis sabia o que queria quando insistiu em colocar a idéia no texto".

Caldeira (1995, p. 227)

A inserção de artigos regulamentando atividades de Banqueiros (Título IV) ${ }^{7}$, Hipoteca e Penhor Mercantil (Título XIII), Companhias e Sociedades Comerciais (Título XV), apenas para citar algumas, constituía-se em um vislumbre de atividades futuras, bastante avançadas para a época. No mais, o Código voltava-se para o fim precípuo para o qual havia sido criado: a atividade mercantil.

\footnotetext{
${ }^{6}$ Segundo SIMONSEN (1939, pp. 22-3), "Em torno de 1850, contava o país com pouco mais de 50 estabelecimentos industriais, incluindo algumas dezenas de salineiras. Há referências a 2 fábricas de tecidos, 10 de indústrias de alimentação, 2 de caixas e caixões, 5 de pequena metalurgia, 7 de produtos químicos, nas quais estavam empregados capitais de ... cerca de 780 mil libras esterlinas".

7 Os "Títulos" acima se referem às divisões capitulares empregadas na estrutura do Código Comercial Brasileiro.
}

bulge of the laws, our first accounting standards and orientations appeared.

\section{THE BRAZILIAN COMMERCIAL CODE}

Laws do neither arise coincidentally nor suddenly. Even though the socio-economic evolution of the country was still rather modest in that time ${ }^{6}$, it started to demand clearer rules for its exercise. Consequently, a commission was constituted, which was specifically formed for this purpose, and in which the Baron of Mauá, quoted above, had a relevant participation, as can be understood from the following text:

"Em 1851 seria criado o Banco do Commercio e da Industria do Brasil. [...] Uma empresa como aquela não poderia ser fundada sem o novo Código Comercial, que entre outras coisas previa a formação de sociedades anônimas. No momento em que a lei foi escrita [1850] não havia o menor indício de gente disposta a fundar uma delas - mas o industrial travestido de redator de leis sabia o que queria quando insistiu em colocar a idéia no texto". ${ }^{7}$

Caldeira (op. cit, p. 227)

The insertion of articles that regulated activities of Bankers (Title IV) ${ }^{8}$, Trade Mortgage and Pawnbrokerage (Title XIII), Commercial Companies and Societies (Title XV), just to quote a few, constituted a glimpse of future activities that were rather advanced for the age. For the rest, the Act was directed at the main purpose for which it had been created: the activity of trade.

\footnotetext{
${ }^{6}$ In accordance with SIMONSEN (1939, p. 22-3), "Em torno de 1850, contava o paiz com pouco mais de 50 estabelecimentos industriaes, incluindo algumas dezenas de salineiras. Ha referencias a 2 fabricas de tecidos, 10 de industrias de alimentação, 2 de caixas e caixões, 5 de pequena metallurgia, 7 de produtos chimicos, nas quaes estavam empregados capitaes de ... cerca de 780 mil libras esterlinas". (sic) (trans.) "Around 1850, the country had a bit more than 50 industrial establishments, including various tens of salt-works. References are made to 2 factories of cloth, 10 of the food industry, 2 of boxes and coffins, 5 of small metallurgy, 7 of chemical products, in which about 780 thousand pounds sterling were applied".

7 (trans.) "In 1851, the Brazilian Bank of Commerce and Industry would be created. [...] This kind of company could not not be founded without the new Commercial Law, which, among other things, foresaw the formation of Company Law . At the moment the law was written [1850], there did not exist the slightest indication that people were willing to found one of these - but the industrial dressed as a law editor knew what he wanted when he insisted on putting the idea in the text".

${ }^{8}$ The "Titles" above refer to the chapter divisions applied in the structure of the Brazilian Commercial Law.
} 
No texto do Código, criado em 1850, são abordados alguns poucos assuntos de cunho eminentemente contábil e que, por isso mesmo, merecem ser destacados:

Art. 10. Todos os comerciantes são obrigados:

1. A seguir uma ordem uniforme de contabilidade e escrituração, e a ter os livros para esse fim necessários;

2. A fazer registrar no registro do Comércio todos os documentos, cujo registro for expressamente exigido por este Código, ...

3. A conservar em boa guarda toda a escrituração, correspondências e mais papéis pertencentes ao giro de seu comércio, ...

4. A formar anualmente um balanço geral do seu ativo e passivo, o qual deverá compreender todos os bens de raiz, móveis e semoventes, mercadorias, dinheiros, papéis de crédito, e outra qualquer espécie de valores, e bem assim todas as dívidas e obrigações passivas;...

Art. 11. Os livros que os comerciantes são obrigados a ter indispensavelmente, na conformidade do artigo antecedente, são o Diário e o Copiador de cartas.

Art. 12. No Diário é o comerciante obrigado a lançar com individuação e clareza todas as operações de comércio, letras e outros quaisquer papéis de crédito que passar, aceitar, afiançar ou endossar, e em geral tudo quanto receber ou despender de sua ou alheia conta, seja por que título for, sendo suficiente que as parcelas de despesas domésticas se lancem englobadas na data em que forem extraídas do caixa. ...

No mesmo Diário se lançará também em resumo o balanço geral (art. 10, no 4), devendo aquele conter todas as verbas deste, apresentando cada uma verba a soma total das respectivas parcelas; e será assinado na mesma data do balanço geral.

No copiador o comerciante é obrigado a lançar o registro de todas as cartas missivas que expedir, com as contas, faturas ou instruções que as acompanharem.

Art. 13. Os dois livros sobreditos devem ser encadernados, numerados, selados e rubricados em todas suas folhas por um dos membros do Tribunal de Comércio respectivo, ...
In the text of the Act, created in 1850, a few subjects are approached which are eminently related to the accounting area and which, therefore, deserve to be highlighted:

Art. 10. All the merchants are obliged:

1. To follow a uniform order of accounting and bookkeeping, and to have the books necessary for this purpose;

2. To have all the documents, whose registration was demanded by this Act, registered in the register of Commerce, ...

3. To maintain in good conditions the entire bookkeeping, correspondence and other papers belonging to the daily business of their trade,...

4. To construct annually a general balance sheet of its assets and liabilities, which should include all real estate, furniture and animals, merchandise, cash, credit papers, and any other items of value, as well as all of the debts and liabilities;...

Art. 11. The books which all of the merchants are indispensably obliged to have, in conformity with the preceding article, are the Journal and the Letter book.

Art. 12. In the Journal, the merchant is obliged to enter, with separation and clearness, all of the trade operations, letters and any other credit papers that occur, are accepted, guaranteed or endorsed and, in general, everything received or spent from their own or another's account, because of which certificate whatsoever, being it sufficient that the domestic expense items are entered within the date on which they were taken from cash. ...

In the same Journal will also be entered, in a resumed way, the general balance sheet (art. 10, No 4), which must include all of its entries, each representing the total sum of the respective items; on the same date, the general balance sheet will be signed.

In the letter book, the merchant is obliged to enter the register of all of the letters he may send, with the accounts, notes or instructions that may accompany them.

Art. 13. The two books mentioned above must be bound, numbered, sealed and signed in all of their pages by one of the members of the respective Court of Commerce, ... 
Art. 14. A escrituração do livro será feita em forma mercantil, e seguida pela ordem cronológica de dia, mês e ano, sem intervalo em branco, nem entrelinhas, borraduras, raspaduras ou emendas.

Art. 16. Os mesmos livros, para serem admitidos em Juízo, deverão achar-se escritos no idioma do país; ...

Considerando-se que o Código Comercial, em sua edição original, possuía setecentos e noventa e seis artigos, cabe perguntar: por que menos de uma dezena de artigos foram reservados às práticas contábeis?

A resposta a essa pergunta é facilmente obtida quando se verifica que a comissão de redação era constituída pelos principais comerciantes da época e alguns juristas encarregados de dar forma à Lei. Aos comerciantes não interessava dar contas de suas atividades a ninguém além de seus sócios, isso caso eles existissem. Vale lembrar a quantidade quase que nula de sociedades anônimas anteriormente a 1850.

Um dos reflexos dessa concentração de interesses pode ser extraído do próprio texto do Código. Os artigos 17 e 18 são verdadeiras obras-primas de corporativismo:

Art. 17. Nenhuma autoridade, Juízo ou Tribunal, debaixo de pretexto algum, por mais especioso que seja, pode praticar ou ordenar alguma diligência para examinar se o comerciante arruma ou não devidamente seus livros de escrituração mercantil, ou neles tem contido algum vício.

Art. 18. A exibição comercial dos livros de escrituração comercial por inteiro, ou de balanços gerais de qualquer casa de comércio, só pode ser ordenada a favor dos interessados em questões de sucessão, comunhão ou sociedade, administração ou gestão mercantil por conta de outrem ou em questões de quebra.

Foram dentro desses poucos e singulares parâmetros contábeis que se desenvolveram as atividades comerciais no Brasil, ao longo dos anos 50. Dez anos se passariam até que razões muito específicas levassem à edição de outras normas de caráter contábil.

Em 22 de Agosto de 1860, foi publicada a Lei 1.083: Contendo providências sobre os Bancos de
Art. 14. The keeping of the book will be done in a mercantile form, and the chronological order of day, month and year will be followed, with neither blanks, nor items written between two lines, scribbling, erasures or amendments.

Art. 16. The same books, in order to be admitted in Court, must be found written in the country's language;...

Considering that, in its original edition, the Commercial Code possessed seven hundred ninetysix articles, it is suitable to ask: why less than ten articles were reserved for accounting practices?

The answer to this question is easily obtained when it is verified that the commission which composed the Act was constituted by the main merchants of that age and some jurists charged with formalising the Act. To the merchants, it was of no interest to account for their activities to anybody except their partners, if these would exist. It should be reminded that the quantity of Company Law before 1850 was almost equal to zero.

One of the reflections of this concentration of interests can be extracted from the Act text proper. Articles 17 and 18 are true masterpieces of corporativism:

Art. 17. No authority, Court or Tribunal, under no pretext whatsoever, for how specious it may be, can practice or order any investigation in order to examine whether the merchant does or does not duly keep his mercantile books, or whether they contain any flaws.

Art. 18. The commercial exhibition of commercial bookkeeping books as a whole, or of general balance sheets of any commercial house, can only be ordered in favour of those that have interest in matters of succession, common property or partnership, mercantile administration or management on account of another person or in matters of crash.

It was among these few and singular accounting parameters that commercial activities developed in Brazil during the fifties. Ten years would pass before very specific reasons would lead to the edition of other accounting norms.

On August 22 1860, Act 1.083 was published, 
emissão, meio circulante a diversas Companhias e Sociedades.

\section{AS RAZÕES QUE LEVARAM À LEI 1.083}

O Banco do Commercio e da Indústria do Brasil, criado em 1851 e poucos meses depois rebatizado Banco do Brasil, era uma sociedade anônima presidida por um expressivo acionista, o futuro Barão de Mauá. Sua criação se deu em um momento em que a extinção do tráfico de escravos deixava poucas opções de investimento àqueles que dispunham de capitais, a maioria constituída por ex-comerciantes de escravos. Concebido para captar e fornecer recursos, a juros bastante inferiores aos praticados pelos agiotas da época, o Banco do Brasil logo se tornou atrativo ao capital nacional estagnado, ávido por investi-lo em negócios próprios ou em títulos nos quais esperavam ver aumentada sua fortuna.

Com uma balança comercial equilibrada e até com alguma sobra de dinheiro em caixa, o Brasil atravessava um momento auspicioso que dava espaço à cultura, às artes, ao incremento do convívio social e à discussão de idéias mais liberais.

O Banco do Brasil era um dos principais propulsores desses novos tempos e Mauá, seu principal gestor, com seu arrojo e visão progressista, o artífice que multiplicava recursos e empreendia a industrialização, os transportes e a infra-estrutura (água corrente e iluminação pública) do país. Mauá era o homem do momento e isso alterava o status quo.

Se de um lado tais mudanças trouxeram novas perspectivas econômicas e comportamentais aos investidores e à sociedade da época, para alguns tais novidades eram nefastas. Entre os que a ela se opunham, posto que tais alterações constituíam uma ameaça à forma de governo instituída, estava o Imperador.

Para restabelecer o estado da arte, os adversários de Mauá, tendo o principal dirigente da nação a guiá-los nos bastidores, fomentaram uma onda de boatarias que tinham por objetivo levar a população a duvidar da segurança de um mercado fi- containing measures on emission Banks, legal tender for various Companies and Societies.

\section{THE REASONS THAT LED TO ACT 1.083}

The Banco do Comércio e da Indústria do Brasil, which was created in 1851 and which was, a few months after, renamed Banco do Brasil, was a public limited company presided by one expressive stockholder, the future Baron of Mauá. Its creation occurred at a moment in which the extinction of slave traffic left few investment options to those that had capital at their disposal, most of them constituted by former slave traders. Conceived in order to fund and provide resources, at interest rates that were rather lower than those practised by the money-lenders of that age, the Banco do Brasil soon became attractive for the national, stagnant capital, eager to invest it into their own businesses or in bonds which they hoped would increase their fortune.

With a commercial balance in equilibrium and even with some money left in cash, Brazil went through an auspicious time, which gave room to culture, arts, the increase of social conviviality and to the discussion of more liberal ideas.

The Banco do Brasil was one of the main propellors of these new times and Mauá, its main manager, with his boldness and progressive view, the artisan that multiplied resources and undertook the industrialisation, transportation and infrastructure (running water and street lighting) of the country. Mauá was the man of the moment and this changed the status quo.

If on the one hand such changes gave new economic and behavioural perspectives to the investors and to society of that age, for some, such novelties were fatal. Among the opponents, since such alterations constituted a threat to the established form of government, was the Emperor.

In order the re-establish the state-of-the-art, the adversaries of Mauá, having the main leader of the nation at their disposal to guide them backstage, promoted a wave of rumours aimed at leading the population to doubt the security of a financial market 
nanceiro confinado nas mãos da iniciativa privada. $O$ resultado de tais articulações foi uma corrida de saques ao Banco do Brasil que fez com que, em menos de uma semana, Mauá fosse forçado a regociar a entrega do Banco ao governo para evitar a faiência da instituição, uma vez que as captações encontravam-se investidas em diversas empresas que não propiciavam, em tão curto espaço de tem.. po, a necessária liquidez.

Tendo logrado seu intento e para assegurar a existência de uma instituição bancária única, o governo imperial determinou que os estatutos de qualquer sociedade anônima deveriam ter aprovação governamental para seu funcionamento. Ficavam, ciesta forma, resguardadas quaisquer outras iniciativas futuras.

Obrigado a se desfazer da instituição financeira que funcionava como holding de seus empreendimentos, Mauá iria procurar caminhos legais que permitissem a consecução de seus objetivos. A brecha seria encontrada ṇo próprio Código Comercial e denominava-se sociedade em comandita, ou empresa de responsabilidade limitada.

A grande vantagem deste tipo de empreendimento era que, para seu funcionamento, bastava apenas a autorização da Junta Comercial, e neste tipo de sociedade o governo não podia intervir.

Em 1854, Mauá resolveu fazer então uma sociedade em comandita, porém com o capital dividido em ações ao portador e de livre negociação. A lei era omissa à fórmula encontrada por ele. '

O diferencial da empresa de Mauá sobre outras empresas do gênero, instaladas no país, era que entre seus sócios encontravam-se banqueiros in. gleses de quem ele captava dinheiro no exterior, colocando no mercado nacional a juros de mercado, bem maiores que os de captação, ganhando na diferença das taxas. Adicioraimente, em função de agir nas duas portas, a veiocidade de desconto dos títulos era muito maior que a de seus concorrentes, o que fez com que, em pouco tempo, sua instituição fosse procurada por negociantes de todo o confined in the hands of private initiative. The result of such articulations was a race of drafts to the Banco do Brasil which, in less than one week, forced Mauá to negotiate the delivery of the Bank to the government in order to avoid the institution's bankruptcy, since funding was invested in various companies that did not provide the necessary liquidity in such a short time-span.

Having achieved its purpose and in order to guarantee the existence of one unique banking institution, the imperial government determined that the statutes of any public limited company, in order to function, should be approved by the government. In this way, any other future initiatives remained guarded.

Under the obligation to get rid of the financial institution that functioned as a holding of his undertakings, Mauá was going to look for legal ways that would allow him to achieve his objectives. The breach would be found in the Commercial Code itself and would be called sociedade em comandita ${ }^{9}$, or limited liability company.

The great advantage of this type of undertaking was that, for its functioning, the authorisation of the Commercial Council was sufficient and the government could not intervene in this type of company.

In 1854 then, Mauá decided to create a sociedade em comandita, however, with the capital divided into freely negotiable bearer shares. The law had omitted the formula found by him.

The great advantage Mauá's company had over other companies of this kind installed in the country was that, among his partners, there were English bankers from which he gathered funds abroad, which he brought onto the national market at market interest rates, far above the funding rates, so that he won through the difference in rates. Additionally, in order to act on both sides, the speed at which the bonds were discounted was much faster than that of his competitors which, in a short time, made merchants from all over the world with branches in Brazil call on 
mundo com filiais no Brasil. Para agilizar e expandir seus negócios, fez abrir diversas casas de câmbio em vários pontos do país e no exterior (Uruguai, Paraguai e Argentina).

Enquanto a empresa prosperava e Mauá gozava de alguma paz, o comando econômico do império dividia-se em duas facções: de um lado o Presidente do Banco do Brasil, Visconde de Itaboraí, defensor fervoroso do padrão ouro ${ }^{8}$; do outro lado, o Ministro da Fazenda, Souza Franco, partidário da livre iniciativa e da liberação do crédito.

O antagonismo político entre um presidente de banco, sequioso por limitar a qualquer custo a emissão sem lastro e um ministro disposto a pôr novos e maiores recursos em circulação, não tardou a ocorrer. Não obstante sua posição hierárquica, o ministro dependia da boa vontade do Banco do Brasil, leia-se Itaboraí, para a emissão de papel moeda, quando era necessário.

O ponto alto da briga ideológica se deu em 13 de Novembro de 1857, quando a notícia de uma crise bancária nos Estados Unidos provocou forte elevação do câmbio, na cidade do Rio de Janeiro. Necessitando de numerário para fazer frente aos compromissos assumidos, o Ministro da Fazenda solicitou nova emissão ao Banco do Brasil, no que foi ignorado. Sem saída, recorreu à instituição de Mauá que não apenas pôs à sua disposição o montante necessário, como também pré-fixou e sustentou a cotação da moeda. Ao fazê-lo, Mauá apostava que, passada a crise, haveria excesso de Libras inglesas no mercado e falta de Reais (nome da moeda brasileira, naquela ocasião) e que a Libra Esterlina seria então cotada abaixo do Real, no momento em que oferecera apoio ao ministro.

$\mathrm{Na}$ esteira desses acontecimentos e para consagrar o rompimento político, o Ministro autorizou seis bancos de províncias a emitirem títulos. Estava desfeito o monopólio bancário engendrado quatro anos antes, quando da assunção do Banco do Brasil como único banco do país.

Durante o período que durou a crise - cerca de his institution. In order to make his business more agile and expand, he had various exchange houses opened in various points in the country and abroad (Uruguay, Paraguay and Argentina).

While the company thrived and Mauá enjoyed some peace, the economic command of the empire was divided into two factions: on the one hand, the President of the Banco do Brasil, Visconde de Itaboraí, ardent defender of the gold standard ${ }^{10}$. On the other hand, the Minister of Finance, Souza Franco, supporter of free initiative and the liberation of credit.

The occurrence of political antagonism between the president of a bank, eager to limit issuing without guarantee at any cost, and a minister willing to bring new and greater resources in circulation, was not far off. In spite of his hierarchical position, the minister depended on the goodwill of the Banco do Brasil, that is, Itaboraí, for the emission of paper money, when that was necessary.

The summit of the ideological fight occurred on November 13 1857, when the news of a banking crisis in the United States provoked a strong exchange increase in the city of Rio de Janeiro. In need of cash to face the compromises assumed, the Minister of Finance asked the Banco do Brasil for a new emission, for which he was ignored. With no exit left, he resorted to Mauá's institution which not only put the necessary sum at his disposal, but also prefixed and sustained the currency's rate. Doing this, Mauá bet that, once the crisis had passed, there would be an excess of English Pounds on the market and a lack of Reais (name of the Brazilian currency at that time) and that the Pound Sterling would then be rated below the Real, at the moment he would offer support to the minister.

In the wake of these events and in order to consecrate the political rupture, the Minister authorised six provincial banks to issue bonds. This meant the dissolution of the banking monopoly, devised four years earlier, when the Banco do Brasil had assumed as the only bank in the country.

During the period in which the crisis lasted-about

\footnotetext{
${ }^{8}$ Segundo essa doutrina econômica, a moeda-ouro funcionava como um padrão ou medida de valor inalterável. As emissões de papel de um país deveriam, à medida do possível, estar atreladas ao equivalente em reservas auríferas.
} 
cinco meses - as críticas e acusações trocadas entre Itaboraí e o ministro movimentaram e dividiram a opinião pública nacional, todos apostando que as projeções de Mauá estariam erradas e que se o inverso ocorresse o governo brasileiro teria de pagar uma fortuna à instituição de Mauá.

Passada a turbulência cambial, que mostrou o quanto o ministro agira certo em sua ousadia, uma vez que Mauá acertara em suas projeções, ainda assim, uma nova onda de ataques políticos se abateu sobre ambos. Souza Franco, por "sugestão" do Imperador, renunciou. Quanto a Mauá, foi novamente perseguido em suas iniciativas.

\section{O PERIGO DA "ANARQUIA MONETÁRIA"}

Em fevereiro de 1858, Itaboraí solicitou à diretoria do Banco do Brasil que aprovasse um documento, chamando a atenção do Imperador para o "perigo da anarquia monetária" que autorizou o funcionamento de novos bancos. Atribuía a crise à superabundância de papel moeda. Para saná-la, propunha a restrição do crédito através da elevação gradual da taxa de descontos e para pôr o país novamente no rumo, pedia ao novo Ministro da Fazenda, Torres Homem, político de carreira e pouco familiarizado com economia, que adotasse "as medidas que sua sabedoria julga convenientes", como forma de bloquear o estabelecimento dos bancos concorrentes que o ministro anterior havia aprovado.

O novo ministro aproveitou a deixa e, alegando que só o legislativo poderia autorizar o funcionamento das instituições bancárias, revogou o decreto de seu antecessor e mandou a questão para o Parlamento. A seguir, baixou um decreto obrigando o Banco do Brasil a enxugar suas emissões e propôs "a volta ao regime de circulação metálica", ou seja, a volta do princípio do padrão ouro.

Essas medidas provocaram grandes discussões plenárias, mas acabaram sendo aprovadas por estreita margem de votos. No dia seguinte à vitória de seu Ministro da Fazenda, o Imperador, para apaziguar os ânimos, solicitou-lhe a renúncia. O novo ministro, Ângelo Muniz da Silva Ferraz, era ainda mais five months - the criticism and accusations exchanged between Itaborai and the minister moved and divided national public opinion, all of them betting that Mauá's projections were wrong and that, if the opposite occurred, the Brazilian government would have to pay a fortune to Mauá's institution.

After the exchange turbulence had passed, which showed how the minister acted correctly in his audacity, since Mauá was right in his projections, nevertheless, a new wave of political attacks fell down on both of them. At the "suggestion" of the Emperor, Souza Franco resigned. As a result of his initiatives, Mauá was again pursued.

\section{THE DANGER OF "MONETARY ANARCHY"}

In February 1858, Itaboraí asked the board of directors of the Banco do Brasil to approve a document, attracting the attention of the Emperor to the "danger of monetary anarchy" that authorised the functioning of new banks. He attributed the crisis to the great abundance of paper money. In order to resolve the crisis, he proposed credit restriction by means of the gradual elevation of the discount rate and, in order to put the country on the right track again, he asked the new Minister of Finance, Torres Homem, career politician and not very familiarised with economy, to adopt "the measures that his wisdom thought convenient", as a way of blocking the establishment of the competing banks the previous minister had approved.

The new minister made good use of the cue and, alleging that only the legislative power could authorise the functioning of banking institutions, revoked the decree of his predecessor and sent the question to Parliament. Next, he passed a decree obliging the Banco do Brasil to dry up its issues and proposed "the return to the regime of metal circulation", that is, the return to the gold standard principle.

These measures provoked great discussions in Parliament, but ended up being approved by a strict margin of votes. The day after the victory of his Finance Minister, the Emperor, in order to appease spirits, solicited him for his resignation. The new minister, Ângelo Muniz da Silva Ferraz, was even more 
radical que seu antecessor e iniciou uma série de medidas de impacto.

\section{A LEI 1.083 DE 22 DE AGOSTO DE 1860 E SEU CONTEÚDO}

A Lei 1.083, conquanto tenha trazido algumas contribuições à área contábil, como será visto mais à frente, detém um nível de autoritarismo somente comparável aos Decretos e Atos Institucionais exarados no golpe de 1964.

Por proposta ministerial, qualquer sociedade anônima, bancária ou não, só poderia ser fundada depois que seus estatutos fossem aprovados pelo Parlamento e posteriormente pelo Executivo, como segue:

Art. 2. Na organização e regimen das Companhias e Sociedades Anonymas, assim civis como mercantis, observar-se-hão as seguintes disposições:

$\S 1^{\circ}$. As Companhias ou Sociedades Anonymas, Nacionaes ou Estrangeiras, suas Caixas Filiaes ou Agencias, que se incorporarem ou funcionarem sem autorização concedida por Lei ou por Decreto do Poder Executivo, e aprovação de seus estatutos ou escripturas de associação, [...] pagarão a multa de 1 a 5\% do mesmo capital....

§ 3‥ A autorização e aprovação [...] deverá ser solicitada por intermédio do Governo, o qual, ouvida a respectiva Secção do Conselho de Estado, remetterá à Assembléia Geral os documentos e informações que julgar conveniente.

Talvez por considerar que, uma vez aprovada, a sociedade poderia escapar ao controle governamental, o Art. 1., em seu parágrafo $7^{\circ}$, instituiu um fiscal nomeado pelo governo com as seguintes competências:

1. Fiscalizar todas as operações do Banco e as deliberações de seu Conselho Administrativo, e da Assembléia Geral dos Acionistas, e suspender a execução das que forem contrárias aos estatutos e à presente Lei, dando immediatamente conta ao Governo para que este decida se devem ser ou não executadas.

4. Examinar a escripturação do Banco todas as vezes que for a bem do interesse público. radical than his predecessor and started a series of impact measures.

\section{ACT 1.083 OF AUGUST 221860 AND ITS CONTENTS}

Although it made some contributions to the accounting area, Act 1.083, as will be seen further ahead, possesses a level of authoritarianism that can only be compared to the Decrees and Institutional Acts written in the coup of. 1964.

By ministerial proposal, any public limited company, whether it was a bank or not, could only be founded after its statutes had been approved by Parliament and afterwards by the Executive Power, as follows:

Art. 2. In the organisation and ruling of Company Law and Societies, civil as well as mercantile, the following regulations will be observed:

\$1. The Company Law or Societies, whether National of Foreign, their Branch Banks or Agencies, that incorporate or function without authorisation given by Law or by Decree from the Executive Power, and without approval of their statutes or memoranda of association, [...] will pay a fine of 1 to $5 \%$ of the same capital....

$\S 3$. The authorisation and approval [...] must be solicited through the intermediary of the Government, which, after hearing the respective Section of the State Council, will pass to the General Assembly the documents and information it may consider appropriate..

Perhaps by considering that, once approved, the society could escape from governmental control, Art. 1., in its $7^{\text {th }}$ paragraph, instituted an inspector appointed by the government with the following competence:

1. To inspect all of the operations of the Bank and the deliberations of its Administrative Council, and of the General Assembly of Shareholders, and to suspend the execution of those that go against the statutes and the present Law, immediately notifying the Government in order to decide whether they shall or shall not be executed.

4. To examine the bookkeeping of the Bank each time this is in the interest of the public. 
É nesse tópico 4., acima, que retira dos comerciantes as prerrogativas contidas nos artigos 17 e 18 do Código Comercial, que surgem os motivos que levariam os redatores da lei a definir pela primeira vez na história do Brasil a obrigatoriedade da publicação de balanços e documentos prescritos em lei, como segue:

$\S$ 9․ Os gerentes ou directores das Companhias ou Sociedades Anonymas, de que trata o $\S$ 1 - deste artigo, serão obrigados a publicar e remetter ao Governo, nos prazos e pelo modo estabelecido nos seus Regulamentos, os balanços, demonstrações e documentos que por estes forem determinados, sob pena de multa de ....

O texto da Lei 1.083 não continha nenhuma informação adicional sobre o formato de tais balanços; no entanto, esse assunto seria regulamentado em 3 de Novembro de 1860, pelo Decreto 2.679.

\section{DECRETO N. 2.679 - DE 3 DE NOVEMBRO DE 1860}

Impõe aos Bancos e outras Companhias e Sociedades Anonymas a obrigação de remeter em certas épocas ás competentes Secretarias de Estado seus balanços e outros documentos.

Para efeito de análise exclusivamente contábil, cumpre destacar os seguintes parágrafos do Decreto:

Art. 1․ As Administradoras, Diretorias ou Gerencias dos Bancos, as suas Caixas Filiaes ou Agencias são obrigadas a publicar até o dia 8 de cada mez, nos lugares em que funccionarem, os balanços de suas operações effetuadas no mez antecedente, e a enviar duas copias authenticas, a saber: huma ao presidente da respectiva Província e outra ao Ministério da Fazenda;

$\S 2 .^{\circ}$ Os balanços mensaes serão organizados na forma dos modelos annexos ao presente Decreto.

Art. 2․ As demais Companhias ou Sociedades Anonymas, assim civis como mercantis, publicarão pelo menos semestralmente, ou nas épocas marcadas nos seus Estatutos, os do-
It is in this topic 4., above, which withdraws from the merchants the privileges contained in articles 17 and 18 of the Commercial Code, that the motives arise which would bring the composers of the law to define, for the first time in the history of Brazil, the obligation to publish balance sheets and documents prescribed by law, as follows:

§9. The managers or directors of Company Law and Societies, treated in $\S 1$ of this article, will be obliged to publish and forward to the Government, in accordance with the terms and ways established in its Regulations, the balance sheets, statements and documents that were determined by them, on pain of a fine of...

The text of Act 1.083 did not contain any additional information on the format of such balance sheets, however, this subject would be regulated on November 3 1860, by Decree 2.679.

\section{DECREE N. 2.679 - NOVEMBER} 31860

Imposes on the Banks and other Public Limited Companies and Societies the obligation to forward to the competent Secretaries of State, at certain time, its balance sheets and other documents.

For an exclusively accounting analysis, the following paragraphs of the Decree must be highlighted:

Art. 1. The Administrations, Boards of Directors or Management of Banks, their Branch Banks or Agencies are obliged to publish, until the $8^{\text {th }}$ day of each month, on the premises they function, the balance sheets of their operations realised in the previous month, and to send two authentic copies, namely: one to the president of the respective Province and another to the Ministry of Finance;

$\S 2$. The monthly balance sheets will be organised in the form of the models annexed to the present Decree.

Art. 2. The other Company Law or Societies, civil as well as mercantile, will publish at least every semester, or at the times marked in their Statutes, the documents treated in the 
cumentos de que trata o artigo precedente, $e$ os remetterão aos respectivos Presidentes e competentes Secretarias de Estado na forma do mesmo artigo.

Os modelos mencionados no $\S 2 .$. diziam respeito às seguintes modalidades de negócios: Bancos com e sem emissão de moeda, Montes de Soccorro (casas de penhor), Companhias de Seguros, Fábricas, Companhias de Navegação, Estradas, Vehiculos de transporte terrestre e Praças.

O texto do Decreto levava ao público os padrões que seriam nacionalmente adotados até que a Lei 2.627 de 1940 apresentasse outras disposições.

Na seqüência serão apresentados os modelos de balanço de Banco, sem emissão, e de balanço para Estradas. (A estrada, neste caso, deve ser entendida como uma empresa empreiteira.)

Adicionalmente, serão mostrados quadros de um balanço de cada uma dessas atividades, publicados na época. No que diz respeito ao banco, coincidentemente será mostrado o balanço da holding dos empreendimentos do Barão de Mauá, a Casas Mauá \& C., de 31 de dezembro de 1867, naquela ocasião uma das maiores empresas do mundo. Para que se tenha uma idéia do que significavam os $\$ 115.8$ contos de réis, em ativos, das empresas de Mauá, basta mencionar que o capital do maior banco do mundo na ocasião, o Banco de Londres, não chegava a quatro vezes esse montante e que o orçamento do Império, naquele mesmo ano, correspondia a $\$ 97$ mil contos de reis.

No que se refere a Estrada, será apresentado um balanço datado de 13 de Outubro de 1860, relativo à Companhia da Estrada de Mangaratiba - RJ, acompanhado de um demonstrativo de receitas e despesas elaborado na mesma ocasião. preceding article, and will forward them to the respective Presidents and to the competent Secretaries of State in the form of the same article.

The models mentioned in $\S 2$. refer to the following business forms: Banks with and without the issuing of currency, Montes de Soccorro (pawnshops), Insurance Companies, Factories, Shipping Companies, Roads, ground transportation Vehicles and Markets.

The text of the Decree published the standards that would be adopted on a national basis until Act 2.627 from 1940, would present other regulations.

Next, the balance sheet models for Banks, without issuing, and for Roads will be presented (the road, in this case, must be understood as a contractor company.)

Additionally, authentic copies will be shown of a balance sheet of each of these activities, published at that time. What the bank is concerned, coincidentally, we will show the balance sheet of the holding of the enterprises of the Baron of Mauá, Casas Mauá \& C., on December 31 1867, then one of the biggest companies in the world. In order to have an idea about the meaning of the $\$ 115.8$ contos de réis in assets of Mauá's companies, it is sufficient to mention that the capital of the biggest bank in the world at that time, the Bank of London, did not reach four times this amount, and that the budget of the Empire, in the same year, corresponded to \$97 mil contos de réis.

What the Road is concerned, a balance sheet will be presented, dated October 131860 , referring to the Companhia da Estrada de Mangaratiba (Mangaratiba Road Company) - RJ, accompanied by an income statement elaborated on the same occasion. 


\section{MODELO DE BALANÇO PARA BANCOS SEM EMISSÃO}

1860

\begin{tabular}{|c|c|c|c|c|}
\hline \multicolumn{3}{|c|}{ Banco ... (a denominação delle) } \\
Meze anno
\end{tabular}

\section{BALANÇO DAS CASAS MAUÁ \& C.}

31 de Dezembro de 1867

\begin{tabular}{|c|c|c|c|}
\hline \multicolumn{4}{|c|}{$\begin{array}{c}\text { Resumo dos balanços das casas Mauá \& C., em } 31 \text { de Dezembro de } 1867 \text { comprehendendo } \\
\text { a casa matriz e todas as suas filiaes }\end{array}$} \\
\hline Activo & & Passivo & \\
\hline 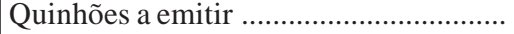 & 10.000:000\$000 & Capital & 20.000:000\$000 \\
\hline Liquidação de Mauá, Mac. Gregor \& C ... & $6.394: 689 \$ 238$ & Fundo de reserva ....... & $1.874: 249 \$ 901$ \\
\hline 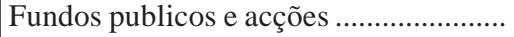 & 17.634:090\$978 & 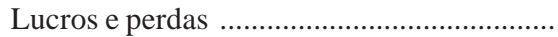 & $1.250: 174 \$ 725$ \\
\hline 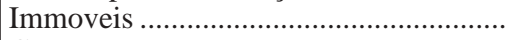 & $12.731: 247 \$ 380$ & Emissão nas Republicas Oriental e Argentina .. & $10.579: 212 \$ 511$ \\
\hline 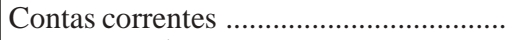 & $26.424: 554 \$ 414$ & 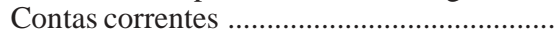 & $36.173: 940 \$ 296$ \\
\hline Letras a receber ... & $9.158: 298 \$ 623$ & Letras por dinheiro a premio ... & $11.529: 736 \$ 230$ \\
\hline 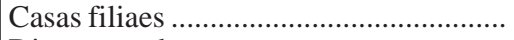 & $15.988: 216 \$ 394$ & Letras a pagar .......................... & $10.518: 666 \$ 480$ \\
\hline 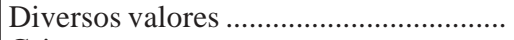 & $3.646: 475 \$ 889$ & Casas filiaes ............ & $20.248: 973 \$ 272$ \\
\hline 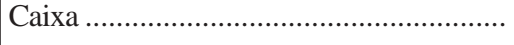 & $13.209 .306 \$ 290$ & Diversos valores ............... & $3.011: 925 \$ 701$ \\
\hline & $\overline{115.186: 879 \$ 206}$ & & $\overline{115.186: 879 \$ 206}$ \\
\hline
\end{tabular}

MODELO DE BALANÇO PARA CIAS. DE ESTRADA

1860

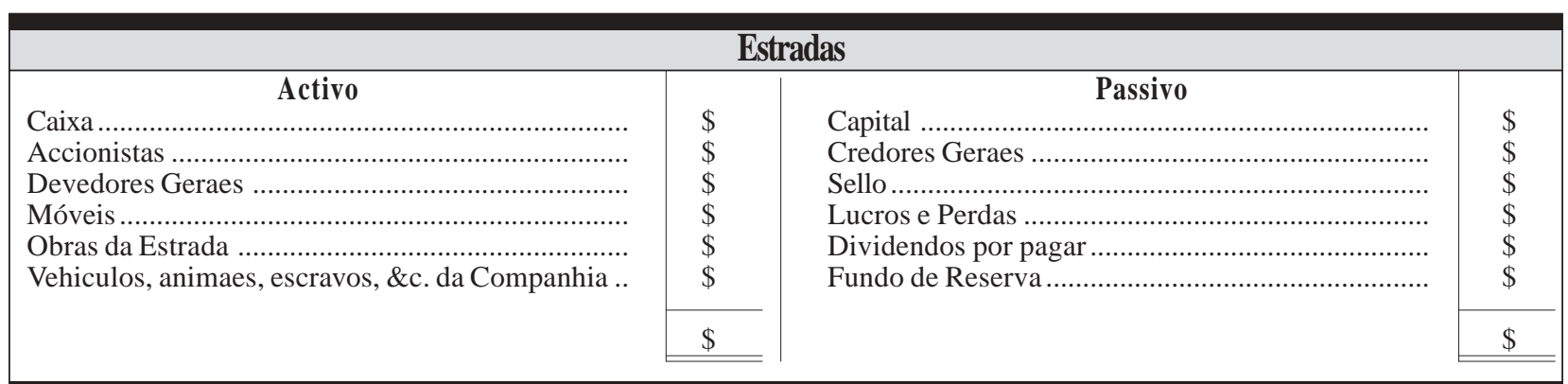




\section{BALANÇO DA CIA. ESTRADA DE MANGARATIBA 13 de Outubro de 1860}

Balanço offerecido ao Juiz da Fallencia pela Curadoria Fiscal das contas representativas do seu activo e passivo, extrahido da escripturação respectiva em 13 de Outubro de 1860, data alcançada pela arrecadação feita em Mangaratiba, e na qual se encerrão as referidas contas.

\begin{tabular}{|c|c|c|c|}
\hline Activo & & Passivo & \\
\hline Estrada de Mangaratiba . & $1.993: 298 \$ 015$ & Capital. & 2.500:000\$000 \\
\hline Canal de Guaratiba ............ & $938 \$ 770$ & Fundo de reserva ...... & $6: 422 \$ 276$ \\
\hline 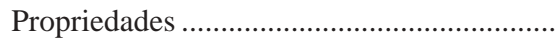 & $142: 277 \$ 723$ & Dividendos ........................... & 3:033\$000 \\
\hline Trem rodante & $6: 450 \$ 000$ & 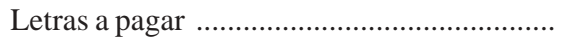 & $45: 678 \$ 964$ \\
\hline 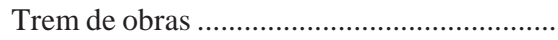 & $14: 654 \$ 340$ & Ordens a pagar & $58: 429 \$ 186$ \\
\hline 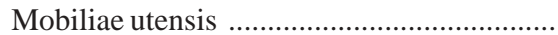 & $1: 031 \$ 475$ & 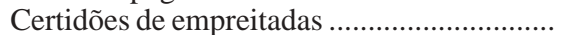 & $240: 658 \$ 840$ \\
\hline Material & $1: 117 \$ 135$ & 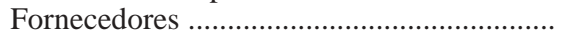 & $53: 398 \$ 456$ \\
\hline 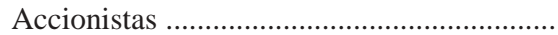 & 1.250:000\$000 & 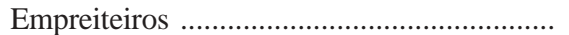 & $158: 145 \$ 598$ \\
\hline Prestações & $7: 500 \$ 000$ & 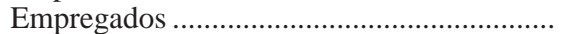 & $9: 889 \$ 861$ \\
\hline 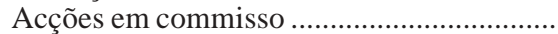 & 18:000\$000 & 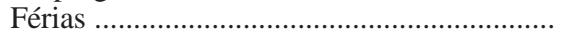 & $4: 318 \$ 949$ \\
\hline 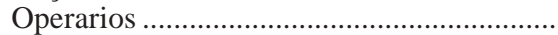 & 27:067\$299 & Credores geraes & $875: 162 \$ 738$ \\
\hline Cobradores de barreiras & $3: 641 \$ 658$ & & \\
\hline 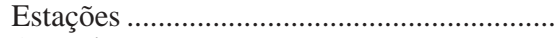 & $8: 130 \$ 708$ & & \\
\hline 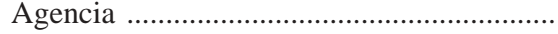 & $208 \$ 010$ & & \\
\hline 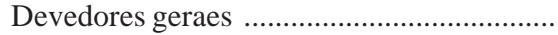 & $404: 889 \$ 589$ & & \\
\hline 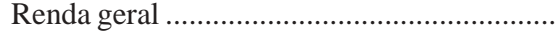 & $75: 855 \$ 147$ & & \\
\hline Réis ..... & $3.955: 059 \$ 868$ & Réis ..... & $3.955: 059 \$ 868$ \\
\hline
\end{tabular}

\section{DEMONSTRATIVO DE RECEITAS E DESPESAS DA ESTRADA DE MANGARATIBA - 1860}

Demonstração resumida da receita e despeza da Companhia da Estrada de Mangaratiba desde a sua organização até 13 de Outubro de 1860, em que foi declarada em fallencia.

RECEITA
Capital realizado em 5 chamadas ..................

Juros contados em $\%$

Renda de barreiras

Dita de transportes

Dita do trapiche

Dita de proprios arrendados

Fundo de reserva ...

Dividendo por pagar

Deficit supprido por empréstimo e

fornecimentos

1.200:000\$000

$151: 934 \$ 474$

$139: 300 \$ 686$

$111: 236 \$ 433$

$33: 217 \$ 025$

$8: 147 \$ 888$

6:322\$276

3:033\$000

$1.623: 281 \$ 782$

$1.445: 604 \$ 592$ $3.068: 886 \$ 374$

\section{DESPEZA}

Custo da estrada

Canal de Guaratiba

Propriedades compradas

Trem rodante e de obras

Mobilias, utensilios e material

Conservação da estrada

Despeza de barreiras

Idem do trem rodante

Idem do trapiche

Dividendos pagos

Commissão da directoria

Juros contados em \%

Em dividas a liquidas

\begin{tabular}{|r|}
$3.068: 886 \$ 374$ \\
$1.993: 298 \$ 015$ \\
$938 \$ 770$ \\
$142: 277 \$ 722$ \\
$21: 104 \$ 340$ \\
$2: 148 \$ 610$ \\
$44: 361 \$ 155$ \\
$9: 882 \$ 361$ \\
$172: 200 \$ 551$ \\
$1: 674 \$ 660$ \\
$29: 700 \$ 000$ \\
$2: 236 \$ 276$ \\
$227: 390 \$ 374$ \\
\hline $2.647: 212 \$ 834$ \\
$421: 673 \$ 540$ \\
\hline $3.068: 886 \$ 374$ \\
\hline
\end{tabular}




\section{CONCLUSÃO:}

Os trechos extraídos do texto da Lei № 1.083, de 22 de Agosto de 1860, acrescidos dos artigos extraídos do Decreto 2.679, de 03 de Novembro de 1860, e das reproduções dos balanços publicados no século XIX - o da Estrada de Mangaratiba, inédito até o momento - são provas cabais e suficientes para demonstrar que a Lei 2.627, de 1940, não é, como se acreditava, a primeira lei brasileira a definir padrões para publicações de balanços.

$\mathrm{Na}$ verdade, analisados os motivos que determinaram a edição da Lei № 1.083, é possível afirmar que foi ela a primeira lei a regulamentar o funcionamento das Sociedades Anônimas no Brasil, ainda que respeitadas as proporções sócio-econômicas entre épocas.

Por outro lado, mais uma vez se confirma o contexto e as origens legalistas sempre presentes na evolução da contabilidade brasileira, fruto de uma herança cultural ibérica onde o que vale é o que está escrito na lei em detrimento das soluções que melhor atendam o exercício das atividades profissionais.

Uma constatação inesperada diz respeito ao uso da contabilidade como instrumento de arbítrio e repressão. Tal uso surpreende, principalmente quando descaracteriza uma atividade que tem por objetivo, pelo menos nos moldes como a idealizamos nos dias de hoje, bem informar e servir a seus usuários.

Para encerrar, espera-se que este trabalho sirva de inspiração para que outros autores busquem em nossas origens contábeis o porquê das coisas.

\section{REFERÊNCIAS BIBLIOGRAFIA}

CALDEIRA, Jorge, Mauá: Empresário do Império, São Paulo, Editora Companhia das Letras, 1995.

CÓDIGO COMERCIAL BRASILEIRO, organização Juarez de Oliveira e Marcus Cláudio Acquaviva, 26. ed., São Paulo, Saraiva, 1981.

FIALHO, D. Branca, A Educação Secundária no Brasil, Rio de Janeiro, Anais do $3^{\circ}$ Congresso de História Nacional, 1938.

FRANCO, Hilário, A Evolução dos Princípios Contábeis no Brasil, São Paulo, Atlas, 1988.
CONCLUSION:

The extracts from the text of Act No 1.083, from August 22 1860, together with the articles extracted from Decree 2.679, from November 3 1860, and from the reproduction of the balance sheets published in the XIXth century - that of Estrada de Mangaratiba, unpublished until date - provide complete and sufficient evidence to demonstrate that Act 2.627, from 1940, is not, as was formerly believed, the first Brazilian law to define standards for balance sheet publication.

Actually, after analysing the motives that determined the edition of Act No 1.083, it can be affirmed that it was the first law that regulated the functioning of Company Law in Brazil, even when respecting the socio-economic proportions between different ages.

On the other hand, the context and legalist origins, always present in the evolution of Brazilian accounting, are again confirmed, being the fruit of an Iberian cultural inheritance, in which what was written in the law was valid, in detriment of the solutions that better attended the exercise of professional activities.

One unexpected conclusion refers to the use of accounting as an instrument of decision and repression. Such use surprises, mainly when it takes away the characteristics of an activity whose aim it is, at least in the forms we idealise it nowadays, to inform well and serve its users.

To finish up, we hope this work will serve as an inspiration for other authors to look into our accounting origins to find the reason of things.

\section{BIBLIOGRAPHY}

CALDEIRA, Jorge, Mauá: Empresário do Império (Mauá: Entrepreneur of the Empire), São Paulo, Editora Companhia das Letras, 1995.

CÓDIGO COMERCIAL BRASILEIRO (BRAZILIAN COMMERCIAL CODE), organização Juarez de Oliveira e Marcus Cláudio Acquaviva, 26. ed., São Paulo, Saraiva, 1981.

FIALHO, D. Branca, A Educação Secundária no Brasil (Secundary Education in Brazil), Rio de Janeiro, Anais do $3^{\circ}$ Congresso de História Nacional, 1938. 
SCHMIDT, Paulo, História do Pensamento Contábil, Porto Alegra, Globo, 2000.

SILVA, Laércio Baptista, A contabilidade no Brasil: aspectos do desenvolvimento por influência da legislação e da contabilidade, São Paulo, 1980, Dissertação - Faculdade de Economia, Administração e Contabilidade da Universidade de São Paulo.

SIMONSEN, Roberto C., A Evolução Industrial do Brasil, FIESP, 1939.

SOARES, Sebastião F., Histórico da Companhia Industrial da Estrada de Mangaratiba, Rio de Janeiro, Typographia Nacional, 1864.

SUZANNET, Conde de, O Brasil em 1845, Rio de Janeiro, Livraria Editora da casa do Estudante, 1957.
FRANCO, Hilário, A Evolução dos Princípios Contábeis no Brasil (The Evolution of Accounting Principles in Brazil), São Paulo, Atlas, 1988.

SCHMIDT, Paulo, História do Pensamento Contábil (History of Accounting Ideas), Porto Alegra, Globo, 2000.

SILVA, Laércio Baptista, A contabilidade no Brasil: aspectos do desenvolvimento por influência da legislação e da contabilidade (Accounting in Brazil: development aspects through the influence of legislation and accounting), São Paulo, 1980, Dissertação - Faculdade de Economia, Administração e Contabilidade da Universidade de São Paulo.

SIMONSEN, Roberto C., A Evolução Industrial do Brasil (Industrial Evolution of Brazil), FIESP, 1939.

SOARES, Sebastião F., Histórico da Companhia Industrial da Estrada de Mangaratiba (History of the Industrial Mangaratiba Road Company), Rio de Janeiro, Typographia Nacional, 1864.

SUZANNET, Conde de, O Brasil em 1845 (Brazil in 1845), Rio de Janeiro, Livraria Editora da casa do Estudante, 1957. 